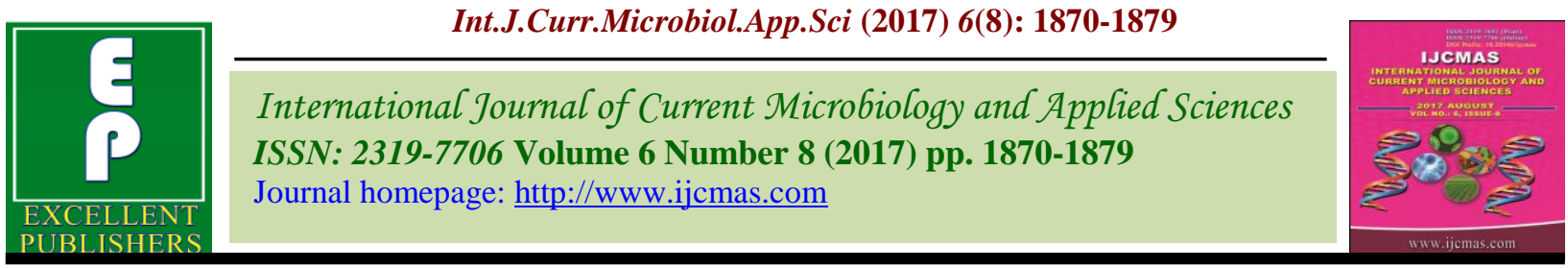

Original Research Article

https://doi.org/10.20546/ijcmas.2017.608.221

\title{
Response of Zinc and Sulphur on Growth and Yield of Rice (Oryza sativa L.) under Sodic Soil
}

\author{
Vikas Singh $^{1}$, Nikhil Raghuvansi ${ }^{1}$, Avanish Kumar Singh ${ }^{2 *}$, \\ Vikash Kumar ${ }^{1}$ and R.A. Yadav ${ }^{1}$ \\ ${ }^{1}$ Department of Agronomy, College of Agriculture, N.D. University of Agriculture and \\ Technology, Kumarganj, Faizabad, Uttar Pradesh (224 229), India \\ ${ }^{2}$ ICAR- Agricultural Technology Application Research Institute, Kanpur, \\ Uttar Pradesh (208 002), India \\ *Corresponding author
}

\begin{tabular}{|c|c|}
\hline & B S T R A C T \\
\hline & \multirow{8}{*}{ 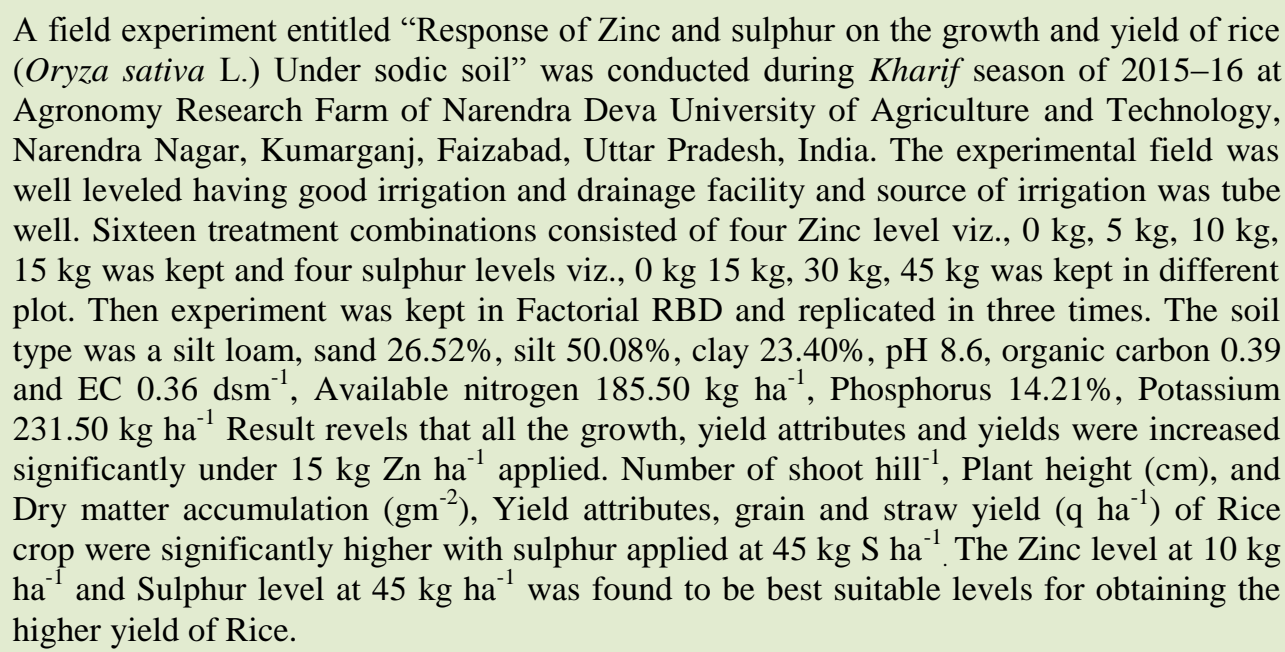 } \\
\hline Keywords & \\
\hline Sulphur level, & \\
\hline & \\
\hline $\begin{array}{l}\text { Dry matter } \\
\text { accumulation. }\end{array}$ & \\
\hline Article Info & \\
\hline $\begin{array}{l}\text { Accepted: } \\
\text { 19 June } 2017 \\
\text { Available Online: } \\
10 \text { August } 2017\end{array}$ & \\
\hline & \\
\hline
\end{tabular}

\section{Introduction}

Rice (Oryza sativa L.) is a popular cereal crop commonly used as human food. It is actually a type of grass and belongs to a family gramineae (poaceae) includes other cereals such as wheat and maize. It is a source of magnesium, thiamin, niacin, phosphorus, Vitamin $\mathrm{B}_{6}$, zinc and copper. Some varieties have iron, potassium and folic acid. White rice is one of the poorest cereals in proteins; some improved varieties however may provide $14 \mathrm{~g}$ of protein in $100 \mathrm{~g}^{-1}$. It is an excellent source of complex carbohydrates, the best source of energy. However, a lot of these nutrients are lost during milling and polishing, which turns brown rice into white rice by removing the outer rice husk and bran to reveal the white grain. In the beginning rice grew wild, but today most countries cultivate varieties belonging to the Oryza type which has around twenty different species. Only two of them offer an agriculture interest for humans, Oryza sativa and Oryza glaberrima. Rice grows under a variety of agro-ecological condition much wider than that for any other 
major crop. It tolerates water as deep as $5 \mathrm{~m}$ in flood prone areas of South and East Asia and grows well in drought prone upland areas of Asia, Latin America and Africa. The geographic range of rice is from the equator to temperatures areas of Northern Japan and South Australia and from sea level to attitudes of more than $2500 \mathrm{~m}$. As a consequences, there is great variability in the soil on which the crop is grown and equally real variability in appropriate varieties and management practices for this crop. Rice being the staple food for more than $70 \%$ of our national population and source of livelihood for 120 150 million rural households is backbone to the Indian agriculture. Rice is cultivated worldwide over an area about 156.69 mha with an annual production of about $660.18 \mathrm{mt}$ with an average productivity of $4.2 \mathrm{t} \mathrm{ha}^{-1}$. (2013-14 according to Ministry of Agriculture) In the latest report, The International Grains Council has projected India's rice production to touch a new record at $107 \mathrm{mt}$ in 2013-14 and area planted under rice has increased to 46 mha. Uttar Pradesh is an important rice growing state in the country. The area and production of rice in this state is about $13.84 \mathrm{mha}$ and $32.64 \mathrm{mt}$, respectively, with productivity of $2358 \mathrm{~kg} \mathrm{ha}^{-1}$ the situation prevailing in our country in global terms is that we have $16 \%$ of human population $15 \%$ of farm animal population $2 \%$ of the forest and $0.5 \%$ grazing land. India entered the distinction of emerging as the second country after china to exploit hybrid vigour in rice, when it successfully developed and released for commercial cultivation the first set of 5 hybrids in 1994. The availability of sulphur gradually limiting in sodic and fine texture soil, poor in organic matter. Zinc deficiency in sodic soils has been recognized as an important and widespread nutritional disorder for growing hybrid rice. Sulphur as essential mineral nutrient plays key roles in protein production chlorophyll formation and oil synthesis. To Sulphur deficiency in crop plants has been recognized as a limiting factor not only for crop growth and seed yield but also for poor quality of products, because Sulphur is a constituent of several essential compounds such as (cystine methionine, coenzyme, thioredoxine and sulpholipids). About $2 \%$ of organic sulphur in the plant is present in the water soluble thiol fraction. Sulphur requirement for optimal growth vary between $0.1 \%$ and $0.5 \%$ of the dry weight basis of plants and its increase in the order of gramineas<leguminaceae<cruciferae. Zinc is one of the important Micro-nutrient which is essential for plant growth. Zn deficiency is the most widespread micronutrient disorder in lowland rice and application of $\mathrm{Zn}$ along with NPK fertilizer increases the grain yield dramatically in most cases (Fageria et al., 2011; Singh et al., 2011). Plant root absorbs zinc as ion $\left(\mathrm{Zn}^{++}\right)$and as component of synthetic and natural molecular complexes can also enter the plant system directly through leaves. Zinc is closely involved in the diversity of enzymatic and $\mathrm{N}$ metabolism of plant in zinc deficient plant protein. Synthesis and level are markedly reduced and amino acid and amides are accumulated. Zinc is the essential mineral for IAA synthesis. Zinc deficiency is closely related to the inhibition of RNA synthesis reduces root and shoot growth and chlorophyll concentration in leaves. The available zinc in Indian soils ranges between 0.08-20.5 ppm. Application of zinc has been found to boost growth and yield of crops to a greater extent. Zinc deficiency continues to be one of the key factors in determining rice production in several parts of the country (Muthukumararaja and Sriramachandrasekharan, 2012) and causes poor tillering leading to decreased productivity of crop. Since zinc is a co-factor carbonic anhydrase and aldosase. Therefore it may adversely affect enzyme activities and carried corresponding metabolic reactions when zinc is deficient in soil. It is also involved in 
synthesis of protein and tryptophane. It is indicated that zinc is an essential structural components for normal functioning of super oxide dismutase enzyme. Aiming the above mentioned views, the present study "Response of Zinc and Sulphur on growth and yield of rice (Oryza sativa L.) Under sodic soil." has been proposed with following objectives:

To study the effect of zinc and sulphur on growth and yield of rice.

\section{Materials and Methods}

The field experiment was conducted at Agronomy Research Farm, Narendra Deva University of Agriculture and Technology, Narendra Nagar, Kumarganj, Faizabad, Uttar Pradesh, India during the Kharif season 2015. The experimental site falls under sub-tropical zone in Indo-gangatic plains and lies between $26^{\circ} 47^{\prime}$ North latitude, $82^{\circ} 12^{\prime}$ East longitudes, at an attitude of about $113.0 \mathrm{~m}$ from mean sea level. The experimental field was well leveled having good irrigation and drainage facility and source of irrigation was tube well. The soil type was a silt loam, sand $26.52 \%$, silt $50.08 \%$, clay $23.40 \%$, pH 8.6, organic carbon 0.39 and EC $0.36 \mathrm{dsm}^{-1}$, Available nitrogen $185.50 \mathrm{~kg} \mathrm{ha}{ }^{-1}$, Phosphorus $14.21 \%$, Potassium $231.50 \mathrm{~kg} \mathrm{ha}^{-1}$. The experiment was laid out in randomized block design with four Zinc level viz., $0 \mathrm{~kg}, 5 \mathrm{~kg}, 10 \mathrm{~kg}, 15 \mathrm{~kg}$ was kept and four sulphur levels viz., $0 \mathrm{~kg} 15$ $\mathrm{kg}, 30 \mathrm{~kg}, 45 \mathrm{~kg}$ with three replications. There were sixteen treatment combinations comprised of 4 zinc and 4 sulphur levels. The nursery sowing was done on 2nd July 2015 and transplanting of rice seedling in experimental field was done as per treatment schedule after 25 days of nursery sowing. 3-4 seedling / hill were transplanted at about $3 \mathrm{~cm}$ depth with row and plant distance $(20 \times 10$ $\mathrm{cm})$. Recommended doses of phosphorus and potash $(60 \mathrm{~kg} / \mathrm{ha})$ were applied through SSP and MOP uniformly before transplanting. However zinc was also applied before transplanting and after transplanting as per schedule of experiment through the zinc oxide in four split doses. Sulphur was applied through gypsum in four split doses considering the total quantity as per plan of the trial. Half of the nitrogen through urea was applied before transplanting in individual plot and the remaining half was applied in two split doses at tillering and panicle initiation stages, respectively. Manual weeding was done with the help of khurpi Ist hand weeding was done at suitable soil moisture just before first top dressing when crop was fully established. Second hand weeding was done before 2 nd top dressing to remove from field and also applied herbicide. Recommended water management schedule for rice was maintained throughout the crop season. Crop was sprayed uniformly by $30 \%$ EC nomini gold liquid @ $250 \mathrm{ml} /$ ha with hand sprayer at 30 days after in early morning hours to prevent the crop losses from weed. Harvesting was done at maturity of the individual plot.

The crop was manually harvested with sickles at the time when the grains were hard enough and contained about $20 \%$ moisture. First of all, the border rows were harvested quite close to the ground plot area was harvested separately and left in same plots for three days to sun drying. Later on, the harvested material from each net plot was carefully bundled, tagged and finally brought to the threshing floor for threshing. The bundle of harvesting produce of each net plot was weighed after compete drying in the sun. The threshing of individual plot was done manually. After cleaning grain yield was recorded in $\mathrm{kg}$ per plot and finally expressed in $\mathrm{q} / \mathrm{ha}$. To obtain straw yield, the grain yield was deducted from total produce. The crop was harvested at proper stage of maturity as determined by visual observations on $10^{\text {th }}$ 
December 2015. Half meter length on either end of each plot and 2 border rows from each side (border rows) were first removed from the field to avoid error. The crop in net plot was harvested for calculation of yield data. Produce was tied in bundles and weighted for biomass yield. Five plants selected randomly were tagged from the net plot area of each treatment for recording various biometric observations and the data collected were analyzed statistically following the procedure described by Gomez and Gomez (1984).

\section{Results and Discussion}

\section{Growth character}

\section{Plant height (cm)}

Plant height was measured at four successive stages. The data related to plant height recorded at 30, 60, and 90 days after transplanting and at harvest as influenced by various levels of Zinc and Sulphur are presented in table 1. Plant height increased as the dose of zinc and sulphur increased at all the stages of crop growth. Zinc application also influenced the plant height significantly at all the stages of crop growth. At 30 DAT there was significant response on plant height noted due to different doses of zinc levels more over $15 \mathrm{~kg} \mathrm{Zn} \mathrm{ha}^{-1}$ zinc responded the higher plant height fallowed by $10 \mathrm{~kg} \mathrm{Zn} \mathrm{ha}^{-1}$. Which was significantly superior over dose of $5 \mathrm{~kg} \mathrm{Zn} \mathrm{ha}^{-1}$ and $0 \mathrm{~kg} \mathrm{ha}^{-1}$ at 60 DAT and the same trend was observed on rest of at all the growth stages of crop.

Further, perusal of data indicate that sulphur application significantly influenced the plant height was recorded higher with higher dose $45 \mathrm{~kg} \mathrm{~S} \mathrm{ha}^{-1}$ being statistically at par with 30 $\mathrm{kg} \mathrm{S} \mathrm{ha}{ }^{-1}$. It was significantly superior over dose of $15 \mathrm{~kg} \mathrm{~S} \mathrm{ha}^{-1}$ and $0 \mathrm{~kg} \mathrm{ha}^{-1}$ and the same tend was observed on rest of at all the growth stages of crop.

\section{Leaf area index}

The data related to leaf area index recorded at 30, 60, and 90 days after transplanting as influenced by various levels of Zinc and Sulphur are presented in table 2. The leaf area index was recorded higher with higher dose $15 \mathrm{~kg} \mathrm{Zn} \mathrm{ha}^{-1}$ being at par with $10 \mathrm{~kg} \mathrm{Zn} \mathrm{ha}^{-1}$ and it was significantly superior over dose of the rest treatment. Same trend was observed at 60 DAT and at 90 DAT it was found decreased. At 30 DAT leaf area index was recorded maximum with $45 \mathrm{~kg} \mathrm{~S}^{-1}$ being at par with $30 \mathrm{~kg} \mathrm{ha}^{-1}$ and significant superior over dose of the rest of the treatment. The same trend was noted at 60DAT, and at 90 DAT was found decreased.

\section{Dry matter accumulation $\left(\mathrm{g} \mathrm{m}^{-2}\right)$}

The data pertaining to dry matter accumulation $\left(\mathrm{g} \mathrm{m}^{-2}\right)$ recorded at 30,60 , and 90 days after transplanting and at harvest as influenced by various levels of Zinc and Sulphur are presented in table 3. The dry weight $\mathrm{g} \mathrm{m}^{-2}$ was recorded maximum with higher dose $15 \mathrm{~kg} \mathrm{Zn} \mathrm{ha}^{-1}$ being at par with 10 $\mathrm{kg} \mathrm{Zn} \mathrm{ha-1} \mathrm{significantly} \mathrm{superior} \mathrm{over} \mathrm{dose} \mathrm{of}$ $5 \mathrm{~kg} \mathrm{Zn} \mathrm{ha}^{-1}$ and $0 \mathrm{~kg} \mathrm{ha}^{-1}$ at 30 DAT and same trend was recorded at all the stage of crop growth. The dry weight $\mathrm{g} \mathrm{m}^{-2}$ was recorded maximum with higher dose $45 \mathrm{~kg} \mathrm{~S}$ $\mathrm{ha}^{-1}$ being at par with $30 \mathrm{~kg} \mathrm{~S} \mathrm{ha}^{-1}$. It was significantly superior over dose of $15 \mathrm{~kg} \mathrm{~S} \mathrm{ha}^{-1}$ and $0 \mathrm{~kg} \mathrm{ha}^{-1}$ at 30 DAT and same trend was recorded at all the stage of crop growth.

Higher doses of $\mathrm{ZnSO}_{4}$ have slightly increased the plant stand, although the difference could not cross the level of significance. This may be due to the fact that in alkaline condition availability of $\mathrm{Zn}$ is restrained. When the zinc oxide was applied, it had helped in quick rejuvenation of seedling and provided the viability to plant and ultimately increased initial plant stand. Plant 
height, number of shoot $\mathrm{m}^{-2}$, leaf area index, and dry matter accumulation $\mathrm{m}^{-2}$ of plant a linear increase in all the parameters was recorded due to increasing doses of zinc levels.The availability of zinc to plants is conditioned by several soil factors, such as $\mathrm{pH}$, organic matter and adsorption by clays. High $\mathrm{pH}$, induced deficiency of zinc occurs in the $\mathrm{pH}$ range from 6 to 8 . Since the $\mathrm{pH}$ of experimental plot was 8.6 all thought the increased solubility of zinc ions with $\mathrm{NaOH}$ or the rise of $\mathrm{pH}$ above 6.5 is a common phenomenon, but in alkaline soils because of the interaction with $\mathrm{Ca}$ in this $\mathrm{pH}$ range, the solubility of this zinc decreases. This may be the reason of poor zinc available in experimental area consequently as the increasing doses of $\mathrm{Zn}$ were applied, they have exhibited their response in linear way.

Since the soil had a tendency of mild salinity and alkalinity, this variation might have been induced due to mortality created by high salt concentration in soil solution due to incorporation of increasing doses of fertilizer. Sulphur plays a pivotal role in protein production, chlorophyll formation and oil synthesis. As it is evident from the data (Tables 1 and 2) that the increasing doses of sulphur have increased the plant height, number of shoot hill ${ }^{-1}$ and leaf area index, and this might due to favorable utilization of sulphur and thus increased the rate of optimal growth.

According to Mrinal and Sharma (2008), First cell division is stimulated in shoot apex, especially in the more basal meristamatic cell from which develop the long files of cortex and pith cell second gibberellins some time promote cell growth because they increase hydrolysis of starch, fructose and sucrose into glucose and fructose molecule. These hexodes provide energy via respiration, they contribute to cell wall formation; and they also make the cell's water potential momentarily more negative. As a result of decreased in water potential, water enters more rapidly causing cell expansion but diluting the sugars. Third hormones (gibberellins) increased wall plasticity of rice plant in which growth promotion of young cells derived from the intercalary meristem is usually dramatic, if the availability of water to rice plant is sufficient. Deficiency of sulphur results in increase in nitrate, soluble organic nitrogenous compounds, amides and ammonia and a decrease in insoluble (protein) nitrogen. $\mathrm{S}$ deficiency symptoms mostly resemble that of $\mathrm{N}$ deficiency. Leaves become pale yellow or light green and the symptoms will persist even after $\mathrm{N}$ application. Plants become small and spindly with short and slender stalks and crop growth is retarded. In sulphur deficient plants, the stem becomes hard woody. According to Singh et al., (2006), sulphur application increases the plant height significantly and the tallest plants were recorded with $45 \mathrm{~kg} \mathrm{~S} \mathrm{ha}^{-1}$ at all the stages. This might be due to rapid growth causes by adequate Sulphur supply to the crop, which resulted increased in various metabolic processes and performed carbohydrate metabolism of the crop plants; thus allowed the plant to grow faster. Results are in agreement to Oh (1991) also recorded significant effect in plant height of rice with successive increased in the dose of sulphur. Number of shoot hill ${ }^{-1}$ was affected significantly by different levels of sulphur at all the stages during the crop season (Table 4). Maximum number of shoots $\mathrm{m}^{-2}$ was found less than $45 \mathrm{~kg} \mathrm{~S}^{-1}$ as compared to $30,15,0, \mathrm{~kg} \mathrm{~S} \mathrm{ha}^{-1}$. This might be due to the fact that higher dose of sulphur (being constituent of Iron sulphur protein and enzymes) has increased the number of shoots $\mathrm{m}^{-2}$, these result are in close accordance to those Oh (1991). Different sulphur levels had significant effect on leaf area index of rice at all the successive stages of the plant growth. Application of $45 \mathrm{~kg} \mathrm{~S}^{-1}$ recorded higher 
value of leaf area index at all the stage (Table 2). This might be attributed to more number of shoot $\mathrm{m}^{-2}$ and increase of plant height which ultimately increased the size and number of green leaves due to favorable utilization of sulphur and thus contributed to higher leaf area index. The lower leaf area index was obtained under low sulphur condition which may produce poor no of shoots $\mathrm{m}^{-2}$ and let to lower leaf area index Chandel et al., (2003) also reported the similar result was found significant increased in leaf area by increasing levels of sulphur. Dry matter accumulation was significantly affected with increased in sulphur levels at all the stages of plant (Table 3 ) this might be due to increased plant height and leaf area index, improved tillering and increased uptake of nutrients reported that results Sarkar et al., (2000).

\section{Yield and yield attributing character}

\section{Number of effective shoots $\mathbf{m}^{-2}$}

Average number of effective shoots $\mathrm{m}^{-2}$ increased as the dose of zinc and sulphur. The maximum number of shoots $\mathrm{m}^{-2}$ (361.28) was noted with the application of $15 \mathrm{~kg} \mathrm{Zn} \mathrm{ha}^{-1}$ followed by at $10 \mathrm{~kg}$ and minimum with lower dose of $5 \mathrm{~kg} \mathrm{ha}^{-1}$ and $0 \mathrm{~kg} \mathrm{Zn} \mathrm{ha}{ }^{-1}$.

The number of effective shoots $\mathrm{m}^{-2}$ was recorded highest (365.87) with higher dose of $45 \mathrm{~kg} \mathrm{~S} \mathrm{ha}^{-1}$ being at par with $30 \mathrm{~kg} \mathrm{~S} \mathrm{ha}^{-1}$ and it was significantly superior over dose of 15 $\mathrm{kg} \mathrm{S} \mathrm{ha}^{-1}$ and $0 \mathrm{~kg} \mathrm{~S} \mathrm{ha}{ }^{-1}$.

\section{Length of panicle}

Length of panicle increased as the dose of zinc and sulphur increases.

There was significantly response noted on higher length of panicle found with $15 \mathrm{~kg} \mathrm{Zn}$ $\mathrm{ha}^{-1}$ (25.72) being at par with $10 \mathrm{~kg} \mathrm{Zn} \mathrm{ha}^{-1}$ significantly superior over dose of $5 \mathrm{~kg} \mathrm{Zn} \mathrm{ha}^{-1}$ and $0 \mathrm{~kg} \mathrm{Zn} \mathrm{ha}{ }^{-1}$.

The length of panicle was recorded highest with higher dose $45 \mathrm{~kg} \mathrm{~S}^{-1}$ (i.e. 25.92) being at par with $30 \mathrm{~kg} \mathrm{ha}^{-1}$ significantly superior over lower dose of $15 \mathrm{~kg} \mathrm{Sha}^{-1}$ and 0 $\mathrm{kg} \mathrm{S} \mathrm{ha}^{-1}$ respectively.

Table.1 Plant height influenced by levels of zinc and sulphur at various stages of crop growth

\begin{tabular}{|c|c|c|c|c|}
\hline Treatment & \multicolumn{4}{|c|}{ Pant height $(\mathrm{cm})$} \\
\hline Zinc levels $\left(\mathrm{kg} \mathrm{ha}^{-1}\right)$ & $30 \mathrm{DAT}$ & $60 \mathrm{DAT}$ & $90 \mathrm{DAT}$ & At harvest \\
\hline \multicolumn{5}{|l|}{ Zinc levels $\left(\mathrm{kg} \mathrm{ha}^{-1}\right)$} \\
\hline $\mathrm{Z}_{0} 0 \mathrm{~kg}$ & 55.48 & 76.35 & 86.05 & 91.70 \\
\hline $\mathrm{Z}_{1} 5 \mathrm{~kg}$ & 58.20 & 80.13 & 90.30 & 96.43 \\
\hline $\mathrm{Z}_{2} 10 \mathrm{~kg}$ & 61.80 & 85.10 & 95.84 & 102.33 \\
\hline $\mathrm{Z}_{3} 15 \mathrm{~kg}$ & 62.78 & 86.46 & 97.48 & 103.98 \\
\hline SEm \pm & 1.217 & 1.659 & 1.907 & 2.031 \\
\hline $\mathrm{CD}(p=0.05)$ & 3.51 & 4.79 & 5.50 & 5.86 \\
\hline \multicolumn{5}{|c|}{ Sulphur levels $\left(\mathrm{kg} \mathrm{ha}^{-1}\right)$} \\
\hline $\mathrm{S}_{0} 0 \mathrm{~kg}$ & 54.60 & 75.08 & 84.63 & 90.25 \\
\hline $\mathrm{S}_{1} 15 \mathrm{~kg}$ & 57.60 & 79.31 & 89.41 & 95.40 \\
\hline $\mathrm{S}_{2} 30 \mathrm{~kg}$ & 62.60 & 86.20 & 97.15 & 103.65 \\
\hline $\mathrm{S}_{3} 45 \mathrm{~kg}$ & 63.45 & 87.45 & 98.48 & 105.13 \\
\hline SEm \pm & 1.217 & 1.659 & 1.907 & 2.031 \\
\hline $\mathrm{CD}(p=0.05)$ & 3.51 & 4.79 & 5.50 & 5.86 \\
\hline
\end{tabular}


Table.2 Leaf Area Index (LAI) at 30, 60, and 90 DAT as influenced by Levels of and zinc and sulphur

\begin{tabular}{|c|c|c|c|}
\hline Treatments & \multicolumn{3}{|c|}{ Leaf area index } \\
\hline Zinc levels $\left(\mathrm{kg} \mathrm{Zn} \mathrm{ha}{ }^{-1}\right)$ & 30 DAT & $60 \mathrm{DAT}$ & $90 \mathrm{DAT}$ \\
\hline $\mathrm{Z}_{0} 0 \mathrm{~kg}$ & 3.44 & 5.12 & 3.91 \\
\hline $\mathrm{Z}_{1} 5 \mathrm{~kg}$ & 3.62 & 5.38 & 4.10 \\
\hline $\mathrm{Z}_{2} 10 \mathrm{~kg}$ & 3.84 & 5.71 & 4.36 \\
\hline $\mathrm{Z}_{3} 15 \mathrm{~kg}$ & 4.90 & 5.80 & 4.43 \\
\hline SEm \pm & 0.07 & 0.11 & 0.08 \\
\hline $\mathrm{CD}(p=0.05)$ & 0.22 & 0.32 & 0.25 \\
\hline \multicolumn{4}{|l|}{ Sulphur levels $\left(\mathrm{kg} \mathrm{S} \mathrm{ha}^{-1}\right)$} \\
\hline $\mathrm{S}_{0} 0 \mathrm{~kg}$ & 3.39 & 5.03 & 3.84 \\
\hline $\mathrm{S}_{1} 15 \mathrm{~kg}$ & 3.58 & 5.32 & 4.06 \\
\hline $\mathrm{S}_{2} 30 \mathrm{~kg}$ & 3.89 & 5.78 & 4.42 \\
\hline $\mathrm{S}_{3} 45 \mathrm{~kg}$ & 3.95 & 5.86 & 4.48 \\
\hline SEm \pm & 0.07 & 0.11 & 0.08 \\
\hline $\mathrm{CD}(p=0.05)$ & 0.22 & 0.32 & 0.25 \\
\hline
\end{tabular}

Table.3 Response of zinc and sulphur on dry matter accumulation of rice

\begin{tabular}{|c|c|c|c|c|}
\hline \multirow{2}{*}{ Treatment } & \multicolumn{4}{|c|}{ Dry matter accumulation $\left(\mathrm{g} \mathrm{m}^{-2}\right)$} \\
\cline { 2 - 5 } & 30 DAT & 60 DAT & 90 DAT & At harvest \\
\hline Zinc levels $\left(\mathrm{kg} \mathrm{ha}^{-1}\right)$ & 213.95 & 558.19 & 693.10 & 843.69 \\
\hline $\mathrm{Z}_{0} 0 \mathrm{~kg}$ & 224.81 & 586.49 & 728.13 & 860.08 \\
\hline $\mathrm{Z}_{1} 5 \mathrm{~kg}$ & 238.68 & 623.45 & 773.18 & 913.26 \\
\hline $\mathrm{Z}_{2} 10 \mathrm{~kg}$ & 242.58 & 632.78 & 785.70 & 928.05 \\
\hline $\mathrm{Z}_{3} 15 \mathrm{~kg}$ & 4.76 & 13.82 & 15.43 & 19.37 \\
\hline $\mathrm{SEm} \pm$ & 13.76 & 39.92 & 44.59 & 55.96 \\
\hline $\mathrm{CD}(p=0.05)$ & 210.53 & 549.14 & 681.85 & 805.41 \\
\hline Sulphur Level $\left(\mathrm{kg} \mathrm{ha}^{-1}\right)$ & 222.44 & 580.37 & 720.63 & 851.21 \\
\hline $\mathrm{S}_{0} 0 \mathrm{~kg}$ & 241.81 & 630.74 & 783.18 & 925.06 \\
\hline $\mathrm{S}_{1} 15 \mathrm{~kg}$ & 245.25 & 640.58 & 794.45 & 963.39 \\
\hline $\mathrm{S}_{2} 30 \mathrm{~kg}$ & 4.76 & 13.82 & 15.43 & 19.37 \\
\hline $\mathrm{S}_{3} 45 \mathrm{~kg}$ & 13.76 & 39.92 & 44.59 & 55.96 \\
\hline $\mathrm{SEm}^{\mathrm{C}}$ & \multicolumn{5}{|c|}{}
\end{tabular}

Table.4 Response of Zinc and sulphur on yield and yield attributes of rice

\begin{tabular}{|c|c|c|c|c|}
\hline \multirow{2}{*}{ Treatment } & \multicolumn{4}{|c|}{ Yield and yield attributes } \\
\hline & Number of shoots $m^{-2}$ & Length of panicle $(\mathrm{cm})$ & No. of Grains panicle ${ }^{-1}$ & Test weight (gm) \\
\hline \multicolumn{5}{|c|}{ Zinc levels $\left(\mathrm{kg} \mathrm{ha}^{-1}\right)$} \\
\hline $\mathrm{Z}_{0} 0 \mathrm{~kg}$ & 312.82 & 21.06 & 161.41 & 22.48 \\
\hline $\mathrm{Z}_{1} 5 \mathrm{~kg}$ & 331.16 & 24.39 & 170.58 & 22.76 \\
\hline $\mathrm{Z}_{2} 10 \mathrm{~kg}$ & 354.74 & 25.63 & 182.37 & 23.04 \\
\hline $\mathrm{Z}_{3} 15 \mathrm{~kg}$ & 361.28 & 25.72 & 190.64 & 23.11 \\
\hline SEm \pm & 7.07 & 0.51 & 3.17 & 0.43 \\
\hline $\mathrm{CD}(p=0.05)$ & 20.43 & 1.47 & 9.17 & 1.24 \\
\hline \multicolumn{5}{|c|}{ Sulphur levels $\left(\mathrm{kg} \mathrm{ha}^{-1}\right)$} \\
\hline $\mathrm{S}_{0} 0 \mathrm{~kg}$ & 306.93 & 21.02 & 158.46 & 22.53 \\
\hline $\mathrm{S}_{1} 15 \mathrm{~kg}$ & 327.23 & 24.31 & 168.61 & 22.81 \\
\hline $\mathrm{S}_{2} 30 \mathrm{~kg}$ & 359.97 & 25.55 & 184.99 & 22.94 \\
\hline $\mathrm{S}_{3} 45 \mathrm{~kg}$ & 365.87 & 25.92 & 192.93 & 23.10 \\
\hline SEm \pm & 7.07 & 0.51 & 3.17 & 0.43 \\
\hline $\mathrm{CD}(p=0.05)$ & 20.43 & 1.47 & 9.17 & 1.24 \\
\hline
\end{tabular}


Table.5 Response of sulphur and zinc on grain yield, straw yield and harvest index of rice

\begin{tabular}{|c|c|c|c|}
\hline Treatment & Grain yield $\left(\mathrm{q} \mathrm{ha}^{-1}\right)$ & Straw yield $\left(\mathrm{q} \mathrm{ha}^{-1}\right)$ & Harvest index (\%) \\
\hline Zinc Level $\left(\mathrm{kg} \mathrm{ha}^{-1}\right)$ & 34.01 & 45.20 & 42.93 \\
\hline $\mathrm{Z}_{0} 0 \mathrm{~kg}$ & 38.20 & 50.05 & 43.15 \\
\hline $\mathrm{Z}_{1} 5 \mathrm{~kg}$ & 42.00 & 55.10 & 43.19 \\
\hline $\mathrm{Z}_{2} 10 \mathrm{~kg}$ & 44.03 & 57.82 & 43.29 \\
\hline $\mathrm{Z}_{3} 15 \mathrm{~kg}$ & 0.82 & 1.07 & 0.52 \\
\hline $\mathrm{SEm} \pm$ & 2.38 & 3.10 & $\mathrm{NS}$ \\
\hline $\mathrm{CD}(p=0.05)$ & 35.64 & 47.71 & 42.76 \\
\hline Sulphur level $\left(\mathrm{kg} \mathrm{ha}^{-1}\right)$ & 37.98 & 49.76 & 43.28 \\
\hline $\mathrm{S}_{1} 0 \mathrm{~kg}$ & 41.19 & 54.15 & 43.19 \\
\hline $\mathrm{S}_{1} 15 \mathrm{~kg}$ & 43.19 & 56.54 & 43.29 \\
\hline $\mathrm{S}_{2} 30 \mathrm{~kg}$ & 0.82 & 1.07 & 0.52 \\
\hline $\mathrm{S}_{3} 45 \mathrm{~kg}$ & 2.38 & 3.10 & $\mathrm{NS}$ \\
\hline $\mathrm{SEm}^{-}$ & \multicolumn{3}{|l|}{} \\
\hline $\mathrm{CD}(p=0.05)$ & \multicolumn{3}{|l|}{} \\
\hline
\end{tabular}

Number of grains panicle ${ }^{-1}$

Number of grains panicle ${ }^{-1}$ increased as the dose of zinc and sulphur increased. There was significance effect of number of grains panicle $^{-1}$ recorded with different doses of zinc levels. As well as $15 \mathrm{~kg} \mathrm{Zn} \mathrm{ha}^{-1}$ being at par with $10 \mathrm{~kg} \mathrm{Zn} \mathrm{ha}^{-1}$ significantly superior over dose of $5 \mathrm{~kg} \mathrm{Zn} \mathrm{ha}{ }^{-1}$ and $0 \mathrm{~kg} \mathrm{Zn} \mathrm{ha}^{-1}$. The number of grains panicle ${ }^{-1}$ was recorded highest with higher dose of $45 \mathrm{~kg} \mathrm{~S}^{-1}$ being at par with $30 \mathrm{~kg} \mathrm{~S} \mathrm{ha}^{-1}$ significantly superior over dose of $15 \mathrm{~kg} \mathrm{~S} \mathrm{ha}^{-1}$ and $0 \mathrm{~kg} \mathrm{~S} \mathrm{ha}^{-1}$ respectively.

\section{Test weight}

There was significantly response noted in test weight due to different levels of zinc more over was recorded highest with higher dose application of zinc $15 \mathrm{~kg} \mathrm{Zn} \mathrm{ha}{ }^{-1}$ (23.11) followed by $10 \mathrm{~kg} \mathrm{Zn} \mathrm{ha}{ }^{-1}$. Lowest test weight was noted with $5 \mathrm{~kg} \mathrm{Zn} \mathrm{ha}{ }^{-1}$ and $0 \mathrm{~kg} \mathrm{Zn} \mathrm{ha}^{-1}$.

There was significantly response noted in test weight due to different levels of sulphur more over was recorded highest with higher dose application of sulphur $45 \mathrm{~kg} \mathrm{~S} \mathrm{ha}^{-1}$ (23.10) followed by $30 \mathrm{~kg} \mathrm{~S} \mathrm{ha}^{-1}$. Lowest test weight was noted with lower dose of $15 \mathrm{~kg} \mathrm{~S} \mathrm{ha}^{-1}$ and $0 \mathrm{~kg} \mathrm{~S} \mathrm{ha}^{-1}$.

\section{Grain yield (q ha $\left.{ }^{-1}\right)$}

The grain yield ( $\mathrm{q} \mathrm{ha}^{-1}$ ) was recorded and presented in table 5 . The grain yield was influenced significantly by zinc and sulphur levels. The yield increases gradually as the doses of zinc and sulphur levels were increased. Among zinc levels the higher grain yield (44.03 q ha-1) was recorded due to $15 \mathrm{~kg}$ $\mathrm{Zn} \mathrm{ha}^{-1}$ being at par with $\left(42.0 \mathrm{q} \mathrm{ha}^{-1}\right)$ from 10 $\mathrm{kg} \mathrm{Zn} \mathrm{ha}{ }^{-1}$ significantly superior over dose of $5 \mathrm{~kg} \mathrm{Zn} \mathrm{ha}{ }^{-1}$ and $0 \mathrm{~kg} \mathrm{Zn} \mathrm{ha}{ }^{-1}$. The maximum grain yield (43.19 $\mathrm{q} \mathrm{ha}^{-1}$ ) was recorded from higher dose $45 \mathrm{~kg} \mathrm{~S}$ ha being at par with 30 $\mathrm{kg} \mathrm{S}$ ha (41.19) and significantly superior over dose of $15 \mathrm{~kg} \mathrm{Sha}^{-1}$ and $0 \mathrm{~kg} \mathrm{~S} \mathrm{ha}^{-1}$.

\section{Straw yield (q ha $\left.{ }^{-1}\right)$}

The data regarding straw yield $\left(\mathrm{q} \mathrm{ha}^{-1}\right)$ has been given in table 5 . The straw yield was increasing due to levels of zinc and sulphur gradually as the doses were increased. Under the response of zinc there was significant response on straw yield (57.82 $\left.\mathrm{q} \mathrm{ha}^{-1}\right)$ was noted due to different doses of zinc levels. 15 $\mathrm{kg} \mathrm{Zn} \mathrm{ha}{ }^{-1}$ responded the higher straw yield $\left(55.10 \mathrm{q} \mathrm{ha}^{-1}\right)$ fallowed by $10 \mathrm{~kg} \mathrm{ha}^{-1}$ and significantly superior over dose of $5 \mathrm{~kg} \mathrm{Zn} \mathrm{ha-}$ ${ }^{1}$ and $0 \mathrm{~kg} \mathrm{Zn} \mathrm{ha}^{-1}$. The straw yield $(56.54 \mathrm{q}$ $\mathrm{ha}^{-1}$ ) was recorded highest with higher dose of 
$45 \mathrm{~kg} \mathrm{~S} \mathrm{ha}^{-1}$ being at par with $30 \mathrm{~kg} \mathrm{~S} \mathrm{ha}^{-1}$ and significantly superior over doses of $15 \mathrm{~kg}$ and $0 \mathrm{~kg} \mathrm{~S} \mathrm{ha}^{-1}$.

\section{Harvest index}

The data regarding harvest index (\%) has been given in table 5 . It is clear from the data that various levels of zinc and sulphur did not influence the harvest index and nonsignificantly, taken at after harvesting of the crop.

Yield contributing characters like number of effective tillers number of panicle plant $^{-1}$, panicle length; number of grain panicle ${ }^{-1}$ and test weight was significantly increased with the increasing doses of zinc oxide. This has consequently increased the grain as well as the straw yield of rice crop. If we look into the individual character in tables 4 and 5 we find that a dose of $15 \mathrm{~kg}$ zinc and $45 \mathrm{~kg} \mathrm{~S}^{-1}$ has increased the number of effective shoots by 6.15 and $8.58 \%$ and number of panicle plant $^{-1}$ by 0.52 and $0.65 \%$ respectively as against control. The length of panicle has increased by $0.65 \%$ and number of grains panicle $^{-1}$ was $8.76 \%$ against control. This might be because of the fact that $\mathrm{Zn}$ had also helped in uptake of nitrogen along with other nutrient elements better has consequently increased these values. A doses of $15 \mathrm{~kg}$ Zinc oxide $\mathrm{ha}^{-1}$ has increased grain yield by $7.19 \%$ by application of $45 \mathrm{~kg} \mathrm{~S} \mathrm{ha}^{-1}$ as against control and increased in straw yield was found $16.69 \%$. This may be due to the fact that zinc is present in several dehydrogenate proteins and peptidase enzymes being a constituent responsible for growth hormones, has induced more starch formation promoted seed filling maturation ${ }^{-1}$ and ultimately production. Considering yield attributing characters, it was found that the sulphur levels have significant response on number of effective shoot, number of panicle $\mathrm{m}^{-2}$, length of panicle, number of grains panicle ${ }^{-1}$ and test weight. Consequently the grain and straw yield $\mathrm{q} \mathrm{ha}{ }^{-1}$ has been increased with every increasing levels of sulphur, showing that is heavy feeder of sulphur. Well-developed source and sink capacity of plant has ultimately resulted in higher yield with higher levels of sulphur. The results are in accordance with the results obtained by Sriramachandrasekaran et al., (2004); Bhuvaneswary et al., (2007).

The maximum grain and straw yield were recorded from $45 \mathrm{~kg} \mathrm{~S} \mathrm{ha}^{-1}$. Increase in yield with zinc application might be due to more number of panicle, grain panicle ${ }^{-1}$ and test weight. Higher yield under high nitrogen levels was due to adequate sulphur supply which contributes to increased dry matter production. Productivity of crop is collectively determined by the vegetative growth and yield attributes. Better vegetative growth coupled with higher yield attributes resulted in higher grain and straw yield of rice. Similar result was reported by Mrinal et al., (2008) and Chaudhary et al., (1992).

From the results discussed above it can be concluded that zinc level at $10 \mathrm{~kg} \mathrm{ha}^{-1}$ and sulphur level at $45 \mathrm{~kg} \mathrm{ha}^{-1}$ was found to be most suitable and realize better growth as well as yield.

\section{References}

Bhuvaneswary, R., Srivamchandra, S.M.V., Ravichandran, M., 2007. Effect of organic and grated level of sulphur on rice yield and sulphur use efficiency. Journal of Interacdemicia 11(1), 51-54. 2008

Chandel, R.S., Sudhakar, P.C., Singh, K., 2003. Response of sulphur in rice. Agricultural Review 24(3), 167-174.

Chaudhary, F.A.M., Bodiuzzaman, K., 1992. Effect of different level of potash and sulphur on the growth and yield of 
Pajama rice. Bangladesh Journal of Agricultural Sciences 19(1), 37-40.

Fageria, N. K., Dos Santos, A. B., and Cobucci, T. (2011). Zinc nutrition of lowland rice. Communications in Soil Science and Plant Analysis, 42, 17191727.

Muthukumararaja, T. M., and Sriramachandrasekharan, M. V. (2012). Effect of zinc on yield, zinc nutrition and zinc use efficiency of lowland rice. Journal of Agriculture science and Technology, 8, 551-561.

Singh, A. K., Meena, M. K., and Bharati, R. C. (2011). Sulphur and Zinc Nutrient Management in rice-lentil cropping system. International Conference on "Life Science Research for Rural and Agricultural Development" (pp 66-67). 27-29 December, 2011, CPRS Patna (Bihar).

Singh, G.R., Dwivedi, A.P., Dixit, R.S., 2006. Effect of nitrogen, phosphorus and potassium levels on growth, yield and quality of hybrid rice (Oryza sativa L.). Oryza 43(1), 64-66.

Gomez, K. A., and Gomez, A. A. (1984). Statistical procedures for agricultural research. John Wiley and Sons Inc., Singapore, 2nd Edn.

Mrinal, B., Sharma, S.H., 2008. Effect of rates adds sources of sulphur on growth and yield of rice (Oryza sativa) and soil sulphur. Indian Journal of Agriculture Science, 78(3), 251-253.

Oh, W., 1991. Plant response to sulphur application. Rice Abstract 14(4), 203.

Sarkar, A.K., Swendra, S., Saha, P.B., 2000. Sulphur in balanced fertilization in red and lateritic soils of chloranapuu Plateau of Bihar.

Sriramachandrasekaran, M.V., Buveneswari, R., Ravichandran, M., 2004. Integrated use of organic and sulphur on the rice yield and sustainable soil health in sulphur deficient soil. Plant Archives 4(2), 281-286.

\section{How to cite this article:}

Vikas Singh, Nikhil Raghuvansi, Avanish Kumar Singh, Vikash Kumar and Yadav R.A. 2017. Response of Zinc and Sulphur on Growth and Yield of Rice (Oryza sativa L.) under Sodic Soil. Int.J.Curr.Microbiol.App.Sci. 6(8): 1870-1879. doi: https://doi.org/10.20546/ijcmas.2017.608.221 